\title{
MORPHOANATOMY OF Garcinia madruno (KUNTH) HAMMEL (CLUSIACEAE) UNDER WATERLOGGED CONDITIONS ${ }^{1}$
}

\author{
NATÁLIA DO COUTO ABREU ${ }^{2}$, SUZANA MARQUES BARBOSA ${ }^{3}$ \\ ELY SIMONE CAJUEIRO GURGEL ${ }^{4}$ WENDELL VILHENA DE CARVALHO ${ }^{5}$
}

\begin{abstract}
Garcinia madruno (Kunth) Hammel is a neotropical tree that naturally occurs in terra firme forests and is important as a source of income and medicine for Amazonian populations. This study describes and compares the morphoanatomical responses of plants under conditions of stress and normoxia. Young plants of Garcinia madruno were subjected to two water regimes: daily controlled irrigation and waterlogged for 84 days. Hypertrophic lenticels, adventitious roots and anatomical characteristics of the roots and leaves were evaluated on days $0,21,42,63$ and 84 . There were no changes in leaf structure, but cracks and hypertrophic lenticels appeared on the stems, there was an increase in blackness of the roots and the plants formed adventitious roots to adapt to the flooded environment. The anatomical changes in the roots of the flooded plants were thickening of the exodermis in the main root and of the pericycle in the lateral roots, and a large increase in the amount of aerenchyma. Histochemical tests detected starch in the midrib, mesophyll, stem and root of flooded plants, and in the petiole of control plants. In the waterlogged plants, phenolic compounds were found in the petiole and alkaloids were found in the midrib, petiole and root.

Termos para indexação: Amazon, bacurizinho, stress, fruit, histochemistry.
\end{abstract}

\section{MORFOANATOMIA DE Garcinia madruno (KUNTH) HAMMEL (CLUSIACEAE) SOB CONDIÇÕES DE ALAGAMENTO}

RESUMO - Garcinia madruno (Kunth) Hammel, árvore neotropical, ocorre naturalmente em florestas de terra firme, considerada uma fonte de renda da população da Amazônia, além de sua importância medicinal do látex para curar diversas doenças. O estudo objetivou descrever e comparar as respostas morfoanatômicas das plantas estressadas e em condições de normoxia. Plantas jovens de Garcinia madruno foram submetidas a dois regimes hídricos: controle irrigado diariamente; e alagado, por 84 dias. Lenticelas hipertróficas, raízes adventícias e características anatômicas da raiz e da folha foram avaliados aos $0 ; 21 ; 42 ; 63$ e 84 dias. Não foram observadas modificações na estrutura foliar, no caule surgiram rachaduras e lenticelas hipertróficas, aumento e enegrecimento das raízes, bem como o surgimento de raízes adventícias, como forma de adaptação ao ambiente alagado. As modificações anatômicas nas raízes de plantas alagadas foram o espessamento da exoderme na raiz principal e do periciclo na raiz lateral, além de grande quantidade de aerênquima. Os testes histoquímicos detectaram: amido: nervura central, mesofilo, pecíolo e raiz das plantas alagadas, bem como no pecíolo das controles; apenas nas alagadas foram observados compostos fenólicos no pecíolo e alcaloides: nervura central, pecíolo e raiz.

Termos para indexação: Amazônia, bacurizinho, estresse, frutíferas, histoquímica.

\footnotetext{
$\overline{1}$ (Paper 089-16). Received July 06, 2016 . Accepted January 11, 2017.

${ }^{2}$ Master's degree program in Biological Science - Tropical Botany, Rural Federal University of the Amazon/Emílio Goeldi Museum. E-mail: natacouto@gmail.com

${ }^{3}$ Master's degree studant program in Biological Science - Tropical Botany, Rural Federal University of the Amazon/Emílio Goeldi Museum. E-mail: suzanamarques2006@yahoo.com.br

${ }^{4}$ Studant of Scientific initiation PIBIC/CNPQ in Emílio Goeldi Museum. E-mail: wendell_vilhena@hotmail.com.

${ }^{5}$ Researcher in Emílio Goeldi Musuem. E-mail: esgurguel@museu-goeldi.br
} 


\section{INTRODUCTION}

Garcinia madruno (Kunth) Hammel is commonly known as bacurizinho (Pará), produces small fruits, mainly from January to May, and is native to Amazonia where the fruits are eaten (SACRAMENTO et al., 2007; COSTA et al., 2012). Phytochemical studies of Garcinia have found phenolic compounds, many of which have active principles with pharmacological properties effective against various diseases (PEREIRA et al., 2010).

According to Lorenzi (2009), in Amazonia Garcinia madruno (Kunth) Hammel occurs mainly in terra firme forest on well-drained land. Therefore, understanding the adaptive characteristics of $G$. madruno under inundated conditions is an important step to understanding the survival strategies of this species, especially because it is both ecologically and economically (fruits and wood) important (LORENZI, 2009).

Despite the great importance of G. madruno, information about its morphoanatomical response to flooding requires further study in relation to possible plasticity. Therefore, the objective of the present work was to describe and evaluate G. madruno under flooded conditions by analyzing morphoanatomical aspects.

\section{MATERIAL AND METHODS}

The experiment was conducted in the Jacques Huber Botanical Garden, at the Museu Paraense Emílio Goeldi (MPEG) in Belém, Pará. Samples of the matrices were incorporated under the numbers MG220962 and MG220963, from which seeds were collected to produce the seedlings. Forty seedlings of Garcinia madruno were used in a completely randomized design (CRD) of $2 \times 5$, with two water regimes, control (irrigated daily to replace water lost by evapotranspiration) and waterlogged (water level $5 \mathrm{~cm}$ above soil level), 20 seedlings each, and removal of material on days 0 (T0), 21 (T1), 42 (T2), 63 (T3) and 84 (T4).

Morphological variables (formation of hypertrophic lenticels, adventitious roots at the base of the stem and characteristics of the main and lateral roots) were observed in the waterlogged plants and analyzed each experimental day starting on the $21^{\text {st }}$ day after the soil was waterlogged.

Fresh slides were made from freehand sections (non-fixed samples) stained with astra blue (1:1) and safranin-fast green (1:1) (LUQUE et al., 1996) and mounted in glycerin. For permanent slides, material was fixed in FAA 50 for $24 \mathrm{~h}$, dehydrated (JOHANSEN, 1940), included in hydroxyethylmethacrylate (Leica ${ }^{\circledR}$ historesin; GERRITIS; SMID, 1983), sectioned with a rotating microtome (Leica - SM2010R), stained with $0.05 \%$ toluidine blue, pH 4.7 (O'BRIEN et al., 1964), and mounted in Permout $\mathbb{R}$ (Fisher Chemical). The slides were made using sections of mature leaves (middle region of the petiole, midrib and margin of blade) and the main and lateral roots (collected $4 \mathrm{~cm}$ from the root crown and the apex, respectively).

For the histochemical tests, the following was used: lugol (JOHANSEN, 1940); ruthenium red (GREGORY; BAAS, 1989); Dragendorff's reagent (SVEDSEN; VERPOORT, 1983); 3\% ferric chloride (JOHANSEN, 1940) and Vanillin hydrochloric acid (MACE; HOWELL,1974).

\section{RESULTS}

\section{Morphological analysis}

The Garcinia madruno plants with waterlogged roots had $100 \%$ survival after the induction of stress. The leaves of this species have the following characteristics: opposite, distichous, blades simple, entire, flexible, elliptic, dark green adaxially, light green abaxially, with smooth surface, average size $12.63 \mathrm{~cm}$ long and $5.26 \mathrm{~cm}$ wide, margins entire, apex acute; venation penniveined, craspidodromous, midrib more prominent on abaxial surface, secondary veins at an approximately $90^{\circ}$ angle from midrib. The root type of G. madruno is axial, with a very developed main root and poorly developed secondary roots compared to the main root.

In general, for the morphological parameters evaluated, after five periods of inundation there were no observed changes in the leaf morphology. The waterlogged soil caused the formation of stem cracks starting on the $21^{\text {st }}$ day of inundation and lenticels in the second week; after the third week the lenticels started to become larger, more numerous and hypertrophic.

The appearance of adventitious roots only occurred after three months of inundation. However, during this period of stress, the plants of the treatments presented epinasty (i.e., the leaves curved downward and there were signs of necrosis causing the main and lateral roots to darken, but there were no signs of impending death).

\section{Anatomical analysis}

The common epidermal cells on the adaxial surface, in frontal view, are various dimensions, polygonal and irregularly arranged with slightly sinuous walls (Fig. 1A). The epidermal cells on the 
abaxial surface are very similar; however, they have more sinuous walls, contain druses and there are stomata that are paracytic (Fig. 1B) and randomly shaped (Fig. 1C).

In transverse section, the leaf has heterogeneous dorsiventral mesophyll with a uniseriate epidermis on both surfaces that lacks ornamentation (Fig. 1D). The external periclinal walls are covered with epicuticular wax (Fig. 1E).

The palisade parenchyma comprises only one layer of cells and the fundamental parenchyma 7 to 9 layers, with cells of various sizes, spongy parenchyma, druses and starch grains. Collateral vascular bundles run through the mesophyll and secretory canals interrupt the fundamental parenchyma (Fig. 1F-G).

The midrib, in transverse section, has a biconvex contour and is larger and more prominent on the the abaxial surface. The epidermis is unistratified with cells of various dimensions, which have rounded internal and external periclinal walls, and epicuticular wax on both surfaces. On the abaxial surface there are two layers of collenchyma cells below the the epidermal cells (Fig. 1H).

The vascular system is formed by a concentric central bundle with 4 to 5 elements of xylem surrounded by phloem, and 3 to 4 layers of fibers internally. Starch grains and calcium oxalate druses are common in the cortical parenchyma. Approximately 6 secretory canals on the adaxial surface and 24 secretory canals on the abaxial surface were observed, which are formed by 6 to 14 small, rounded, juxtaposed epithelial cells (Fig. 1I).

The petiole, in transverse section, is cylindrical and semicircular, with a uniseriate epidermis with cells of various dimensions, thick cuticle and 3 to 4 layers of subepidermal collenchyma. The fundamental parenchyma has approximately 21 layers of cells that contain druses, starch grains and random secretory canals with small, round, juxtaposed epithelial cells. The vascular system comprises one bundle in an open arc surrounded by an endodermis layer and fibers (Fig. 1J-K).

Anatomically, there were no differences between the leaf blades of the control and waterlogged treatments during the five periods analyzed. The differences recorded occurred in the main and lateral roots of plants cultivated in waterlogged soil.

The main root of the control plants, in transverse section, is cylindrical with a cuticle and a layer of irregular epidermal cells of different dimensions. The cortex has an exodermis with approximately 31 layers of parenchyma cells with large amounts of starch grains (Fig. 1L). The cortex of the waterlogged plants was similar to the control plants except it had aerenchyma (Fig. 1M).

The vascular bundles are collateral, the xylem is in the form of a cross in the central region and the phloem is alternating. Surrounding the bundles is an endodermis layer and more internally there are 3 to 4 pericycle layers. In the waterlogged plants, the exodermis was multiseriate with 3 to 4 layers.

The lateral roots of the control plants, in transverse section, are cylindrical. The epidermis is uniseriate with a cuticle. Below this, there is an exodermis with 2 to 3 layers followed by approximately 17 layers of fundamental parenchyma with gaps formed by aerenchyma (Fig. 1N). Vascular bundles were in the pith, delimited by an endodermis externally and 3 to 7 pericycle layers internally. The bundles of the waterlogged plants also had an endodermis layer externally, but internally there were 5 to 10 pericycle layers (Fig. 1O).

\section{Histochemical analysis}

The tests on the leaves and roots of Garcinia madruno (table 1) detected the presence of ovoid starch grains in the fundamental parenchyma of the mesophyll (Fig. 2A), midrib (Fig. 2B), petiole (Fig. 2C) and root (Fig. 2D-E) of the waterlogged plants. In the control plants, starch was found near the secretory canals in the petiole (Fig. 2F).

Alkaloids were found in the midrib (Fig. 2G), petiole (Fig. 2H) and root (Fig. 2I), but only in the waterlogged plants. Total phenolic compounds were observed in the secretory canals of the petioles of waterlogged plants (Fig. 2J).

\section{DISCUSSION}

\section{Morphology}

Hypertrophic lenticels, a morphological change frequently related to survival in flooded environments (MOMMER et al., 2006) and found in the species of the present study, allow oxygen to enter and volatile compounds to exit, such as ethylene, ethanol and acetaldehyde, and toxic products of the anaerobic metabolism (KOLB; JOLY, 2009). These structures are connected to channels of aerenchyma that transport $\mathrm{O}_{2}$ to areas of the roots (KOLB; JOLY, 2009).

Roots directly suffer from the effect of inundation, and the areal part of the plant consequently suffers due to root dysfunction, which leads to nutrient and mineral deficiencies (COLMER; VOESENEK, 2009). Colmer and Voesenek, (2009) note that the production of new superficial roots, as found in the present study, is an important adaptive 
mechanism in the resistance to flooding, because they take over the lost function of the original roots.

Thus, the appearance of adventitious roots and hypertrophic lenticels is associated to the adaption of Garcinia madruno to a flooded environment because it inhabits terra firme forest but is resistant to flooding.

\section{Anatomy}

Cronquist (1981); Metcalfe and Chalk (1950) considered the presence of phenolic idioblasts and $\mathrm{CaO}$ crystals in Clusiaceae to be related to protection against herbivores, by causing injury to predators (FINLEY, 1999), and these structures were found in the present work.

Metcalfe and Chalk (1950) considered the following characters as common to the family Clusiaceae: thick cuticle, stomata restricted to the abaxial surface, secretory cavities, $\mathrm{CaO}$ crystals and hypodermis only on the the adaxial surface. In the present study, only the hypodermis was absent.

The thick, waxy cuticle provided greater protection in this study because the waterlogged plants exhibited lower water potential (Medri et al.., 2011).

Metcalfe and Chalk (1950) identified distinct types of vascular structures in petioles of Clusiaceae, where the vascular bundles of Garcinia mangostana L. were completely closed tubes surrounded by collateral bundles; however, it was observed that the bundles in the petiole of Garcinia madruno have a semicircular cylindrical shape.

In the waterlogged roots of Garcinia brasiliensis Mart., Souza et al., (2013) observed a $23.70 \%$ increase in epidermal thickness. In the present study, G. madruno did not exhibit this thickening but there was an increase in the number of layers in the stressed plants, probably to protect the more internal tissues against water and oxygen loss.

\section{Histochemistry}

The occurrence of starch in most organs of flooded plants can be related to reserved energy or to the survival of plants under stressful conditions (KOLB et al., 1998).

Tannic substances are involved in protecting against desiccation, attacks by fungi, bacteria and insects, reducing the nutrient value of the leaves and altering the taste of the plant (MONTENEGRO et al., 1980; FAHN, 1988). In the present study tannins were not detected; possibly, when tannins are absent, phenolic compounds and $\mathrm{CaO}$ crystals protect the plant (CRONQUIST 1981; METCALFE and CHALKE, 1950).
Phenolic compounds, in addition to helping against pathogen attacks, are also used in medicines as antioxidants and in the treatment of cancer and cardiac diseases (COOPER-DRIVER; BHATTACHARYA, 1998). In addition, these compounds are also related to the mechanism of adaption and the resistance of the plant to the environment (ROCHA et al., 2011), a fact that could explain the presence of these compounds only in the waterlogged plants. 

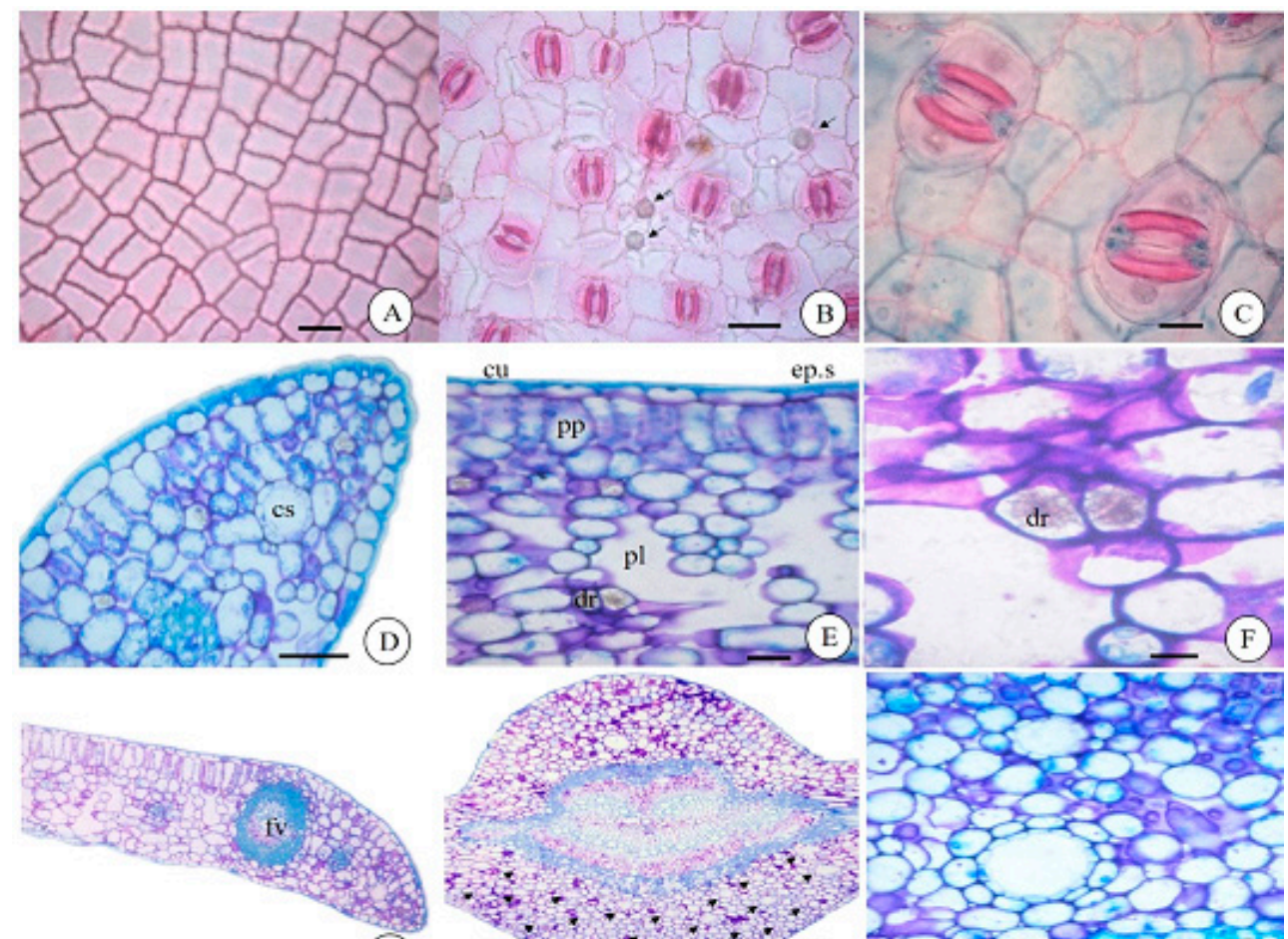

(G)
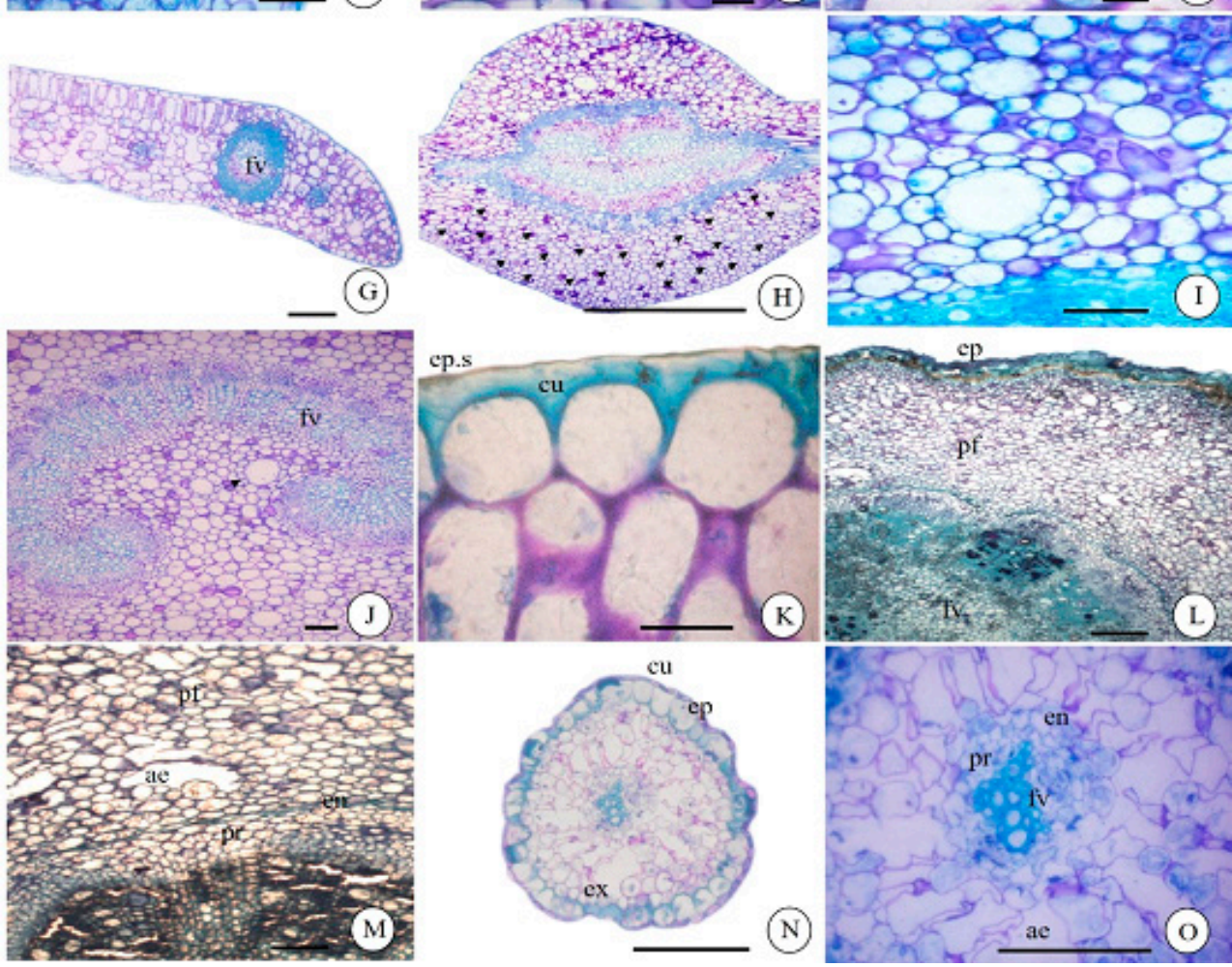

K)

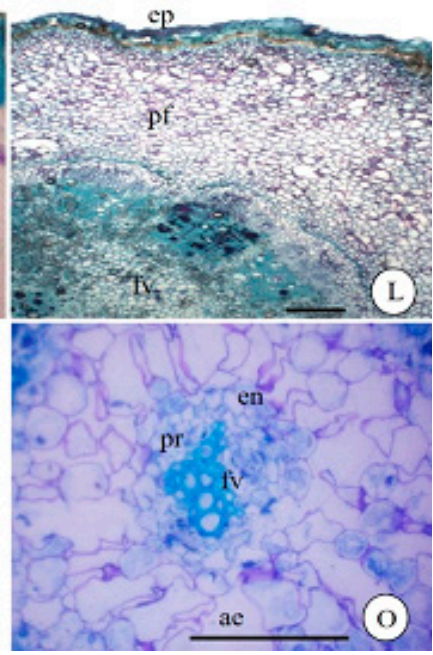

FIGURE 1-Garcinia madruno (Kunth) Hammel. A) Epidermal cells with sinuous contours, adaxial surface; B) Sinuous cell walls and druses (arrows), abaxial surface; C) Parcytic stomata, abaxial surface; D) Secretory canals in the mesophyll; E) Cellular organization of the mesophyll; F) Calcium oxalate druses; G) Vascular bundles in the mesophyll; H) Unistratified epidermis of midrib on both surfaces, subepidermal collenchyma in the abaxial surface, vascular bundle surrounded by fibers and secretory canals (arrows); I) secretory canal; J) Vascular bundle of the petiole in the form of an open arc surrounded by an endoderm and fibers; K) Outer epidermis of the petiole and subepidermal collenchyma; L) Irregular epidermal cells of main root with cuticle and exoderm; M) Fundamental parenchyma of main root; N) Uniseriate epidermis of lateral root; O) Fundamental parenchyma of lateral root. ( $\mathrm{fv}$ - vascular bundle; $\mathrm{cu}$ - cuticle; ep.s - Outer epidermis; $\mathrm{pp}$ - palisade parenchyma; $\mathrm{pl}$ - spongy parenchyma; $\mathrm{dr}$ - druse; cs - secretory canal; ex - exoderm; pf - fundamental parenchyma; ae - aerenchyma; en - endoderm; pr - pericycle). Scales $=2 \mu \mathrm{m}(\mathrm{A}, \mathrm{B}, \mathrm{C}, \mathrm{E}, \mathrm{G}, \mathrm{M}) ; 3 \mu \mathrm{m}(\mathrm{F}) ; 4 \mu \mathrm{m}(\mathrm{I}, \mathrm{K}) ; 10$ $\mu \mathrm{m}(\mathrm{D}, \mathrm{L}) ; 11 \mu \mathrm{m}(\mathrm{O}) ; 32 \mu \mathrm{m}(\mathrm{H}) ; 40 \mu \mathrm{m}(\mathrm{N}), 60 \mu \mathrm{m}(\mathrm{J})$. 


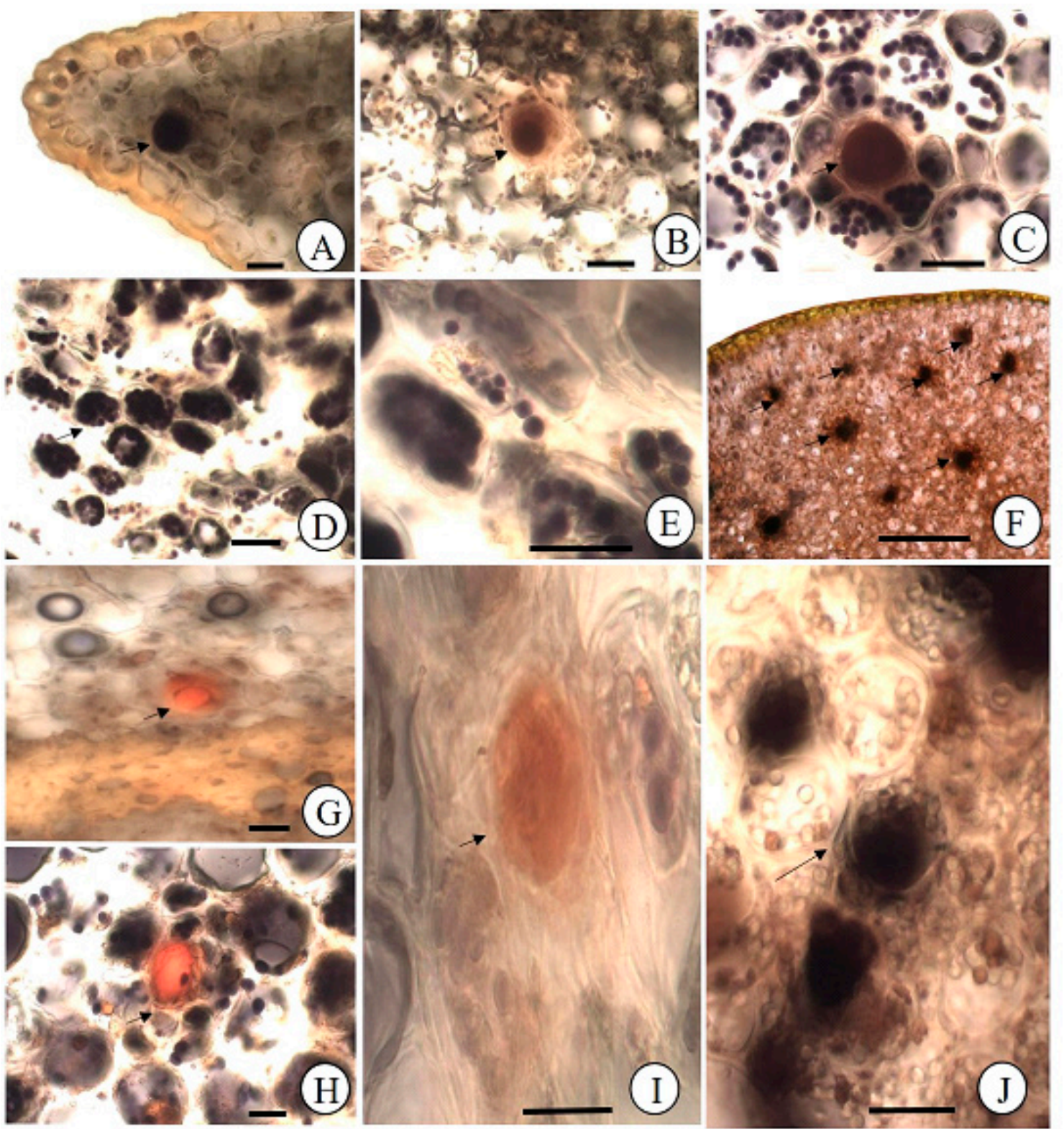

FIGURE 2- Garcinia madruno (Kunth) Hammel. A) Starch grains (lugol) detected in the secretory canal of the mesophyll (arrow); B) Secretory canal in the midrib with starch content (arrow); C) Secretory canal in the petiole with starch (arrow); D and E) Fundamental parenchyma in the root with starch grains; F) Secretory canal in the fundamental parenchyma of the petiole with starch content (arrows); G) Alkaloids (Dragendorff) detected in the secretory canals of the midrib; H) Alkaloids detected in the secretory canals of the petiole; I) Alkaloids detected in the secretory canals of the root; $\mathrm{J}$ ) Total phenolic compounds ( $3 \%$ ferric chloride) observed in the secretory canals of the petiole. Scales $=1,5 \mu \mathrm{m}(\mathrm{A}) ; 2 \mu \mathrm{m}(\mathrm{B}, \mathrm{D}, \mathrm{G}, \mathrm{H}, \mathrm{J}) ; 3 \mu \mathrm{m}(\mathrm{C}) ; 5$ $\mu \mathrm{m}(\mathrm{E}) ; 15 \mu \mathrm{m}(\mathrm{F}) ; 4 \mu \mathrm{m}(\mathrm{I})$. 
TABLE 1 - Garcinia madruno (Kunth) Hammel, location of the compounds detected after histochemical tests of the leaf blades and roots under normal and waterlogged environmental conditions.

\begin{tabular}{ccccccccccc}
\hline Compound & Reagent & \multicolumn{3}{c}{ CO } & & \multicolumn{1}{c}{ AL } & & \\
& & NC & MF & PC & RZ & NC & MF & PC & RZ \\
Alkaloid & Dragendorff & - & - & - & - & + & - & + & + \\
Starch & Lugol & - & - & + & - & + & + & + & + \\
Phenolic compound & Ferric chloride & - & - & - & - & - & - & + & - \\
Tannin & Vanillin hydrochloric acid & - & - & - & - & - & - & - & - \\
Mucilage & Ruthenium red & - & - & - & - & - & - & - & - \\
\hline
\end{tabular}

Legend - + (positive); - (negative); CO (control); AL (waterlogged); NC (midrib); MF (mesophyll); PC (petiole); RZ (root).

\section{ACKNOWLEDGMENTS}

We thank CAPES for awarding the scholarship and for supporting the PNADB (Programa de Apoio ao Desenvolvimento da Botânica, Grant 922/2010).

\section{REFERENCES}

COELHO, C.C.R.; NEVES, M.G.; OLIVEIRA, L.M.; CONCEIÇÃO, A.G.C.; OKUMURA, R.S.; OLIVEIRA NETO, C.F. Biometria em plantas de milho submetidas ao alagamento. Revista Agroecossistemas, Belém, v.5, n.1, p.32-38, 2013.

COLMER, T.D.; VOESENEK, L.A.C.J. Flooding tolerance: suites of plant traits in variable environments. Functional Plant Biology, Victoria, v.36, p.665-81, 2009.

COSTA, R.C.; VERZIGANASSI, J.R.; POLTRONIERI, L.S.; BENCHIMOL, R.L.; CARVALHO, E.A. Rubelose em plantas de bacurizinho no Pará: primeiro relato. Summa Phytopathologica, Botucatu, v.38, n.3, p.255, 2012.

FINLEY, D.S. Patterns of calcium oxalate crystals in young tropical leaves: a possible role as an antiherbivory defense. Revista de Biologia Tropical, San Jose, v.47, n.2, p.27-31, 1999.

GERRITS, P.O.; SMID, L. A new, less toxic polymerization system for the embedding of soft tissues in glycol methacrylate and subsequent preparing of serial sections. Journal of Microscopy, Oxford, v.132, p.81-5, 1983.
JOHANSEN, D.A. Plant microtechnique. $2^{\text {nd }}$ ed. New York: McGraw Hill, 1940.

KOLB, R.M.; JOLY, C.A. Flooding tolerance of Tabebuia cassinoides: metabolic, morphological and growth responses. Flora, Jena, v.204, n.7, p.528-35, 2009.

LORENZI, H. Árvores brasileiras: manual de identificação e cultivo de plantas arbóreas nativas do Brasil. Nova Odessa: Instituto Plantarum, 2009.

LUQUE, R.; SOUSA, H.C.; KRAUS, J.E. Métodos de coloração de Roeser (1972) - modificado - e Kropp (1972) visando a substituição do azul de astra por azul de alcião 8gs ou 8gx. Acta Botanica Brasilica, Porto Alegre, v.10, p.199-212, 1996.

MEDRI, C.; MEDRI, M.E.; RUAS, E.A.; SOUZA, L.A.; MEDRI, P.S.; SAYHUN, S.; BIANCHINI, E.; PIMENTA, J.A. Morfoanatomia de órgãos vegetativos de plantas juvenis de Aegiphila sellowiana Cham.(Lamiaceae) submetidas ao alagamento do substrato.Acta Botanica Brasilica, Porto Alegre, v.25, n.2, p.445-54, 2011.

MEtCAlfe, C,R.; CHALK, L. Anatomy of dicotyledons leaves, stem, and wood in relation to taxonomy with notes on economic uses. Oxford: Claredon Press, 1950. v.2.

MOMMER, L.; LENSSEN, J.P.M.; HUBER, H.; VISSER, E.J.W.; KROON, H. Ecophysiological determinants of plant performance during submergence: a comparative study among seven plant families. Journal of Ecology, Oxford, v.94, n.6, p.1117-29, 2006. 
O'BRIEN, J.S.; FILLERUP, D.L.; MEAD, J.F. Quantification and fatty acid and fatty aldehyde composition of ethanolamine, choline, and serine glycerophosphatides in human cerebral gray and White matter. Journal of Lipid Research, Bethesda, v.5, p.329-38, 1964.

SACRAMENTO, C.K.; JÚNIOR, E.C.; CARVALHO, J.E.U.; MÜLLER, C.H.; NASCIMENTO, W.M.O. Cultivo do mangostão no Brasil. Revista Brasileira de Fruticultura, Jaboticabal, v.29, n.1, p.195-203, 2007.
SOUZA, T.C.; SOUZA, E.S.; DOUSSEAU, S.; CASTRO, E.M.; MAGALHÃES, P.C. Seedings of Garcinia brasiliensis (Clusiaceae) subjected to root flooding: Physiological, morphoanatomical, and antioxidant responses to the stress. Aquatic Botany, Amsterdam, v.111, p.43-49, 2013. 